\title{
Yenilikçi İnsan Kaynakları Uygulamalarının Z Kuşağının Mutluluğuna ve İşten Ayrılma Niyetine Etkisi: Bankacılık Sektöründe Karma Yöntem Araştırması
}

\author{
DOI: $10.26466 /$ opus.585393 \\ * \\ Nihal Güler* - Pınar Acar ** \\ *Öğrenci, Bahçeşehir Üniversitesi, Sosyal Bilimler Enstitüsü, İstanbul / Türkiye \\ E-Posta: nguler80@gmail.com \\ ORCID: 0000-0002-6767-7257 \\ ** Dr. Öğr. Üyesi, Beykoz Üniversitesi, İşletme ve Yönetim Bilimleri Fakültesi, İstanbul / Türkiye \\ E-Posta: pinaracar@beykoz.edu.tr \\ ORCID: $\underline{0000-0002-4290-6383}$
}

Öz

$B u$ araştırmanın temel amacı yenilikçi insan kaynakları uygulamalarının $\mathrm{Z}$ kuşağı çalışanlarının mutluluğuna ve işten ayrılma niyetine etkisini ortaya çıkarmaktır. Araştırmanın örneklemini bankactlı sektöründe bulunan $198 \mathrm{Z}$ kuşağı çalışan oluşturmaktadır. Araştırmamızda karma yöntem (nitel-nicel) benimsenmiştir. Teorik model oluşturulurken öncelikle nitel araştırma deseninden destek alınmıştır. $B$ u doğrultuda $\mathrm{Z}$ kuşağ ç çalışanlar ve yöneticileriyle nitel mülakatlar gerçekleştirilmiştir. Yüz yüze mülakatlar 25 kişiyi kapsayan bir örneklem üzerinden gerçekleştirilmiştir. Yüz yüze görüşme yapılmasının nedeni, katılımcıların kendilerini sinırlama olmaksızın özgürce ifade edebilmeleridir, böylelikle daha derinlemesine veri toplanabilmesi mümkün olmuştur. Verilerin Nvivo 11 nitel veri analizi ile kategorize edilmesi sağlanmıştır. Karma yöntem araştırma stratejisinin ikinci bölümünde teorik modelimizde yer alan değişkenler arası etkileşimi ölçmek amaçlı nicel araştırma yönteminden destek alınmıştır. Veriler 198 çalışandan anket yöntemiyle toplanmıştır ve SPSS 20 paket programıla analiz edilmiştir. Araştırmanın bulguları mutluluğun, yenilikçi insan kaynakları uygulamaları ve işten ayrılma niyeti üzerinde aracı etkiye sahip olduğunu ortaya koymuştur.

Anahtar Kelimeler: Yenilikçi insan kaynakları uygulamaları, Mutluluk, İşten ayrılma niyeti, Z kuşağı, Karma yöntem araştırması. 


\title{
The Effect of Innovative Human Resources Practices on Happiness and Intention to Leave of $Z$ Generation: A Mixed Method Research in the Banking Industry
}

\begin{abstract}
The main objective of this research is to reveal the effects of innovative human resources practices on the happiness and intention to leave on $\mathrm{Z}$ generation employees. The sample of the study consists of $198 \mathrm{Z}$ generation employees in the banking sector. In our study mixed method (qualitative-quantitative) is adopted. Firstly, the qualitative research design was taken as a model. In this respect, qualitative interviews were conducted with $\mathrm{Z}$ generation employees and managers. The face-to-face interviews were conducted with a small sample of 25 subjects. The reason for faceto-face interviews is that participants can freely express themselves without limitation, so that more in-depth data can be collected. Data were categorized by Nvivo 11 qualitative data analysis. In the second part of the mixed method research strategy, the quantitative research method is used to measure the interaction between the variables in our theoretical model. Data were collected from 198 employees by means of survey method and analyzed with SPSS 20 package program. The findings of the study showed that happiness has a mediation effect on innovative human resources practices and intention to leave.
\end{abstract}

Keywords: Innovative human resources practices, happiness, intention to leave, generation $z$, mixed method research 


\section{Giriş}

Araştırmamızın kuramsal altyapısını oluşturan kaynak temelli görüş yaklaşımı, sürdürülebilir rekabet üstünlüğünün sağlaması için, işletmelerin kendi bünyelerinde bulunan kaynaklarının, değerli, nadir, ikamesi olmayan ve taklit edilemeyen nitelikte olmasını öne sürmektedir. Bu doğrultuda potansiyeli yüksek ve yetenekli çalışanların işletmeler için nadir ve değerli kaynaklar olduğu düşünülmektedir. Başarılı ve yenilikçi insan kaynakları uygulamalarıyla potansiyeli yüksek çalışanların mutluluğunu arttırıp işten ayrılma niyetlerini düşürmenin mümkün olduğunu öne sürmekteyiz. Çalışma alanı fark etmeksizin, bulunduğu sektörde faaliyet gösteren tüm işletmeler insan kaynağına gereksinim duymaktadır. İşletmeler rakiplerinden farklılaşarak rekabet avantajı elde etmek için, insan kaynaklarında yönetsel stratejiler geliştirmelidirler. Ayrıca yetenekli ve tecrübeli çalışanın işten ayrılmasının işletmeye maddi ve manevi birçok olumsuz etkisi vardır. İnsanların beklentileri tarihsel süreçler içerisinde sürekli değişmektedir.

Mevcut insan kaynakları uygulamaları günümüz genç çalışanları için yeterli olmamakta, yeni kuşak çalışanlarına, yenilikçi insan kaynakları uygulamalarını benimseyen işletmeler daha cazip gelmektedir. Z kuşağının iş yaşamında, daha fazla esneklik ve mobiliteye sahip olması, teknolojinin ve dijitalleşmenin yoğun kullanımı, çalışan görüşlerinin değerlendirilmesi, sınırsız kariyer anlayışı, hiyerarşik yapının daha az hissedilmesi ve sürekli bir eğitim desteği beklentileri bulunmaktadır. Yaşamının önemli bir bölümünü çalışarak geçiren günümüz insanı için çalışma ortamında mutlu olmak önemli bir konu olarak dikkat çekmektedir. Bu doğrultuda gerçekleştirdiğimiz araştırmamızın ilk bölümü kavramsallaştırma, ikinci bölümü metodoloji, üçüncü bölümü bulgular ve son bölümü tartışma ve sonuç kısmından oluşmaktadır.

\section{Araştırmanın Amacı ve Önemi}

$\mathrm{Bu}$ araştırmanın amacı yenilikçi insan kaynakları uygulamalarının Z kuşağı çalışanlarının mutluluğuna ve işten ayrılma niyetine etkisini ortaya koymaktır. İş hayatına yeni adım atan Z kuşağı gençlerin farklı karakteristik özellikleri ve yönelimlerinin örgütler içerisinde farklılık yaratacağı 
ön görülmektedir. Diğer taraftan, işletmelerin ve diğer kuşakların Z kuşağına yönelik bir çalışma ortamı yaratmaları ve yenilikçi insan kaynakları uygulamalarıyla bu dijital kuşağın mutluluğunu arttırmaları gerekmektedir. İnsanın kaynak yerine değer olarak görüldüğü günümüzde, bir çal1şanın işten ayrılması hem maliyet hem de değer kaybına yol açmaktadır. $\mathrm{Bu}$ yüzden temel hedef işletmelerin çalışanlarıyla uzun soluklu bir serüven yaşamalarıdır. Bu doğrultuda Z kuşağı çalışanların çok iyi irdelenip, onlara yönelik bir model ortaya konmalıdır.

Araştırmamızın önemi de bu bağlamda değerlendirilebilir.

\section{Kavramsallaştırma}

\section{Yenilikçi İnsan Kaynakları Uygulamaları}

İnsan kaynakları yönetimi içeren ilk adımlar 1940'lı yıllarda iş görenlerin kayıtlarını tutmayı içeren personel yönetimi ile başlamıştır. 1950'lerde ise gözlemci niteliğine sahip yeni iş gören birimleri oluşturulmuştur. 1960'l1 yıllarda alt kademe yöneticilerinin, iş görenlerin günlük problemlerinin çözümü için çalışmalar yapması söz konusu olmuştur. 1970'li yıllara ulaşıldığında ise, insan kaynakları yönetiminin kapsamının iyice genişlediği, çalışma ilişkileri seviyesine ulaşıp, orta kademe düzeyinde yer aldığg izlenmiştir. 1980'lerin sonuna gelindiğinde artık insan kaynakları kavramının kullanıldığı ve bizzat insan kaynağından sorumlu ayrı bir yönetim anlayışının oluştuğu görülmüştür (Türedi, 2018, s.4-5). Fordist-Taylorist model ile

1980'li yıllara kadar süren insan kaynaklarının bir maliyet unsuru olarak görülmesi sonrasında, 1980'li yıllarda küreselleşmenin getirisi olarak ortaya çıan teknolojinin gelişmesi, üretimde ve yönetimde modellerin değişmesi ile rekabetin uluslararası sahaya taşınması söz konusu olmuş, insan kaynakları ise stratejik bir boyutta artan bir öneme sahip olmuştur (Rüzgar, 2018, s.6). Çok uluslu şirketlerin artması ve dünya ekonomisi üzerinde güç unsuru olması nedeni ile işletmelerin örgüt yapılarında ve yönetim faaliyetlerinde düzenlemeler ve yenilemeler gereksinimi ortaya çıkmıştır. Özellikle uluslararası işgücü piyasalarından istihdamın işletme başarısını etkilemesi ile uluslararası insan kaynakları yönetimi uygulamalarına dikkat çekilmiştir. İşletmeler işgücü yapılarının farklılığından ötürü 
insan kaynakları uygulamalarında da çeşitliliğe gidilmesine ihtiyaç duymuştur. İnsan kaynakları uygulamaları uluslararası düzeyde bir boyut kazanırken, aynı zamanda örgütlere yetenek ve yaratıcılığın değer kattığı ve bunun yönetilmesinin önem kazandığı anlaşılmıştır. İnsan kaynakları ile örgütsel stratejiler bir arada yönetilmeli ve insan kaynakları yönetimi stratejik bir özellik kazanarak, örgütsel stratejiler ve performans ile ilişki içerisinde olmalıdır. 1980'lerde Japon rekabetinin söz konusu olması ile ortaya çıkan mükemmellik modellerinde, güç barındıran örgütsel kültür yaratma çabaları, kadınların çalışma hayatında daha yoğun yer alması, hizmet sektöründe ağırlık kazanılması ve üstün teknoloji kullanım, işgücü ve iş niteliği açısından değişimler meydana getirmiştir. Bunun sonucu olarak insan kaynakları yönetim yaklaşımlarında da farklı bakış açıları ve yapılanmaların temelleri atılmıştır (Yapıcı-Akar, Dirlik, Kıymalığlu, Yurtseven ve Boz 2011, s.9899). Bu kapsamda aşağıdaki hipotezler oluşmuştur:

- H1 : Yenilikçi Insan Kaynakları uygulamaları işten ayrılma niyetini istatistiksel olarak anlamlı bir düzeyde etkilemektedir.

- H2 : Yenilikçi Insan Kaynakları uygulamalar mutluluğu istatistiksel olarak anlamlı bir düzeyde etkiler.

\section{Mutluluk}

İnsanların doğum anından başlayıp ölüm anına kadar geçirdikleri zamanda yaşamlarının amacı olarak belirledikleri ve anlamlandırdıkları şey mutluluk olmuştur. Bu nedenle insanları mutluluğa ulaştıracak araçların arayışında olmuşlardır. İnsanlığın başlangıç noktasından bu güne arzu duyulan mutluluğu, bireyler toplum içerisinde aramış, süregelen yıllar boyunca ne ifade ettiği ve nasıl elde edileceğine dair birçok araştırma yapılmıştır (Akdeniz, 2016, s.46). Türk Dil Kurumu Mutluluk kavramını "Bütün özlemlere eksiksiz ve sürekli olarak ulaşılmaktan duyulan kıvanç durumu, mut, ongunluk, kut, saadet, bahtiyarlık, saadetlilik" olarak tanımlamaktadır (www.tdk.gov.tr). Mutluluk olgusunun, Eudimonia yani "hayatın kusursuz bir şekilde devam etmesidir" anlamına gelen kavram ile başladığ1 görülmüştür. (Demir, 2017 s.8) Mutluluk, bireylerin arzuladıkları hayat standardını yakalayarak, sağlık - ekonomik durum, eğitim - gelir - refah seviyesi, kültürel - sosyal - fiziksel - aile ve arkadaş çevresi gibi birçok konuda kalite 
olgusu içeren bir seviyede yaşamlarını sürdürebilmelerini ifade eder. (Mameghani, 2017 s.24). Mutluluk, bireyin yaşamının kalitesini bütünüyle değerlendirme derecesi olarak tarif edilmiştir (Güven, 2018 s.36). Mutluluk, bireyin olumlu olarak nitelendirilen duyguları daha sık, olumsuz olarak nitelendirilen duyguları ise daha seyrek yaşaması ve yaşamından fazlaca doyum hissetmesi olarak da tanımlanmaktadır (Mameghani, 2017, s.7). Psikoloji literatüründe ise mutluluk; bireyin kendi yaşam kalitesini düşünerek yaptığı değerlendirmeler sonucunda, iyi bir yaşama sahip olup - olmaması konusundaki kendi olumlu tespitleri olarak kabul görmüştür (Ahat, 2018 s.81). Tarih seyri boyunca içinde bulunulan zamanın şartlarına özgü olarak, her dönemin kendine has mutluluk tanımlanması ve tartışmaları yaşanmıştır. Fakat 21. yüzyıl içerisinde bu alanda yapılan araştırmalar çok önemli olmuştur. Çünkü mutluluk ülkelerde refah ölçütü ve gelişmişlik düzeyinin bir ölçütü olarak kabul görmüştür. Hatta hükümetler kamusal politikaları belirlerken, kapsamı mutluluk olan istatistiksel verilerin sonuçlarından faydalanmış, bu verilerin toplanması amaçlı hem ulusal, hem de uluslararası kurumlar oluşturulmuştur (Gül, 2017 s.21).

Yapılan araştırmalar mutluluk düzeylerinin bu sayede yüksek olduğunu ortaya çıarmaktadır. Annes (1982) bireylerin iş hayatındaki mutluluklarının çalıştıkları kurumda hakim olan hava ile yakın bir ilişkisinin bulunduğunu dile getirmiştir. Mutluluk halini etkileyen faktörlerden bir tanesi de çalışanların, adalet ve ya adaletsizlik algılarıdır. Bu konu geçmiş yıllardan günümüze kadar üzerinde durulan bir konudur. İş yerinde mutluluk, iş tatmini ve örgütsel bağlılı̆g içerir. Mutluluk işyerlerindeki deneyimler, istikrarlı kişi ve düzey tutumları ve kolektif tutumlar ile iş ve organizasyon gibi çoklu odaklar dahil olmak üzere çoklu seviyelerde kavramsallaştırılmış ve ölçülmüştür. Her düzeyde, bireyleri ve örgütleri etkilemiştir. Bu doğrultuda aşağıdaki hipotezimiz oluşturulmuştur:

- H3 : Mutluluk işten ayrlma niyetini istatistiksel olarak anlamlı bir düzeyde etkiler.

\section{İşten Ayrılma Niyeti}

Çalışanların hali hazırdaki işinden veya işyerlerindeki belirlenmiş bir süreçten ayrılmalarına ilişkin düşüncelerinin veya planlarının olması olarak 
tanımlanmıştır. Farklı bir tanım olarak işten ayrılma niyeti; çalışanın işinden veya işyerinden ayrilma konusunda, bilinçli bir şekilde ve temkinli bir niyetinin bulunması yahut ayrılmaya karar vermesi olarak karşımıza çıkmaktadır. Genel bir tanım olarak ise; çalışanın yakın bir zamanda kendi işine son verme düşüncesidir (Gözde, 2018, s.18). İşten ayrılma niyeti, bir sonuç değil işten ayrılmanın bir sürecidir. Bu süreç içerisinde çalışan fırsat bulduğunda işten ayrılma eylemini gerçekleştirebileceği gibi, işten ayrılma ile sonuçlanmaması da söz konusu olabilecektir (Jafarova, 2018 s.64). İşten ayrılma niyeti, çalışanların işten ayrılma ile ilgili kararlarına iki şekilde etki edebilmektedir. Çalışanın başka bir iş olanağı olmamasına rağmen doğruca işten ayrılmasına sebebiyet verebilmektedir. Veya çalışanın yeni iş imkanlarını araştırmasına sebep olarak işten ayrılmasını dolaylı yoldan etkileyebilmektedir (Gürbüz ve Bekmezci, 2012, s.193-194). Bu doğrultuda aşağıdaki hipotezimiz oluşturulmuştur:

- H4 : Yenilikçi İnsan Kaynakları uygulamaları ile işten ayrnlma niyeti arasinda mutluluğun aracilık etkisi istatistiksel olarak anlamlidır.

\section{Z Kuşağı}

Kuşaklara ilişkin gerçekleştirilen araştırmalar incelendiğinde, kuşakların adlandırılması ve belli tarih aralıklarında sınıflandırılması ile ilgili evrensel olarak kabul görmüş bir fikir birliği söz konusu değildir. Literatürde yalnızca bazı tarih aralıklarında ve kuşak tanımlamalarında yaygınlığın bulunduğu sonucuna varılmıştır. Bu araştırmada Z kuşağının sınıfland1rilmasında 1991 ve sonrasını baz alan Oblinger ve Oblinger (2005) sinıflandırması dikkate alınmıştır.

$Z$ kuşağı dijital bir dünyada internete her zaman bağlı ve erişimin çok önemli olduğu bireylerdir. Akıllı telefonları ile diğer elektrikli cihazlara nazaran fazlaca vakit geçirmektedirler. Bu kuşak bebek patlaması ve $X$ kuşağına kıyasla televizyonla daha az zaman harcamaktadır (Hampton ve Keys 2016, s.112). Z kuşağı bireyleri, içerisinde yaratıcılık bulunan aktiviteleri, değişiklikleri, yenilik ve dönüşümcülüğ̈̈ severler. Sonuca odaklı yapıları ile hızlı ve pratiktirler. Edilgen olmak yerine katılımcı ve aktif olmayı tercih ederler. Sosyallikleri çoğunlukla internet erişimi üzerindendir. Sanal dünyada var olmalarının yanı sıra, konuşmaktan çok mesaj atmayı tercih ediyor oluşları iletişim açısından sorun yaşamalarına neden 
olabilmektedir. İstedikleri her türlü bilgiye internetten ulaşabiliyor olmaları, aynı zamanda bağımsızlık ve bireyselliğe düşkünlükleri sabırsızlık göstermelerine neden olmaktadır. Teknoloji bağımlılıkları ve uzaktan iletişime eğilim göstermeleri nedeni ile yalnız yaşamayı tercih edebilirler. Teknoloji ile büyümüş olmalarından dolayı motor becerileri yönünden ve zeka düzeyi olarak daha önceki nesillerden daha üst seviyelerde olduğu tahmin edilmektedir. Teknoloji hayatlarının ayrılmaz bir parçasıdır (Okumuş 2016, s.12). Bireysel, bağımsız ve daha iyi eğitim almış olmaları yaratıcılıklarını olumlu yönde etkilemektedir. Çekinmeden doğrularını iletebiliyor oluşları ise motivasyonu yüksek ortamlar oluşturacaktır. İnternet kullanımı ile coğrafi sınır kavramını kaldırabiliyor oluşları, sosyallik ve iletişime açıklıkları, kuşaklar arasındaki farklılığın giderilmesinde ve birbirlerini anlayabilmeleri açısından önemli etkenler olacaktır. Kendilerini rahatlıkla ifade ediyor oluşları kuşağın olumlu özelliklerindendir (Toruntay, 2011, s.83). Bu kuşak bireyleri önceki kuşaklara göre daha az kardeş ile büyüyor. Küçülen aile boyutunun sonucu olarak bu nesile daha önceki nesillerde olmadığ 1 kadar para, sevgi ve dikkat veriliyor. Bu durum bencil ve benmerkezci olmalarına sebebiyet veriyor. Ayrıca takım oyunu, uzlaşma ve paylaşım konularında sıkıntı yaşıyorlar.

(Singh 2014, s.59-63). Z Kuşağının olumsuz özellikleri ise, niteliklerinin üst seviyede olması kaynaklı, belli türdeki ve tekdüze işleri yapmaları zor olacaktır. Özellikle kriz dönemlerinde azim ve hırstan yoksun olmaları olumsuz etkilere sebebiyet verecektir. Her şeyin kişiye özel olması isteklilikleri zengin ve fakir arasındaki farkın açılmasına sebebiyet verecektir

(İzmirlioğlu 2008, s.50). Z kuşağı bireylerinin marka ve çalıştıkları kurumlara karşı sadakat beslememeleri, hırslı ve azimli olmamaları, çabuk sıkılabilmelerinden kaynaklı olarak kolay vaz geçebilmeleri, şirketlerin gelecekte ellerindeki yetenekleri tutma aşamasında zorluk çekeceklerini göstermektedir. Bireysel standart işleri yapmak istemeyecek, herşeyi kişiselleştirilmiş olarak talep edebileceklerdir (Toruntay 2011, s.83). 


\section{Metodoloji}

\section{Araştırmanın Evren ve Örneklemi}

Bu araştırma İstanbul, Kocaeli ve İzmir bölgelerinde faaliyet gösteren bankaların genç çalışanları üzerine gerçekleştirilmiştir. Araştırma evrenine konu olan 4 banka yeni kuşak çalışanları en fazla istihdam edenler arasında öncü oldukları için seçilmiştir. Araştırmanın örneklemini 4 bankanın 198 çalışanı oluşturmuştur dolayısıyla çalışmanın analiz birimi bireydir.

\section{Ölçek}

Araştırmamızda veri toplama aracı olarak anket tekniği kullanılmıştır. Anketin ilk bölümü demografik sorulardan oluşmuştur. İkinci bölüm, yenilikçi insan kaynakları uygulamaları, mutluluk ve işten ayrılma niyeti değişkenlerine ait ölçeklerden oluşmaktadır. Mutluluk ölçeği; Çalışanların algılanan mutluluk düzeylerini ölçmek üzere 18 sorudan oluşan mutluluk ölçeği Hills ve Argyle (2002) tarafindan geliştirilmiştir. Akdeniz (2016) tarafından sağlık sektöründe uygulanmış ve bu çalışmada Erkuş ve diğerleri (2015) tarafından yapılan güvenilirlik analizleri Cronbach alfa güvenirlik katsayısı 92 olarak tespit edilmiştir. Cevaplar 5'li likert (1=Kesinlikle katılmıyorum, 5=Kesinlikle katılıyorum) ölçeği ile alınmıştır. Stratejik İnsan Kaynakları Uygulamaları Ölçeği, Chen ve Huang (2008)'dan alınmıştır. Başar (2016) tarafından kullanılan ölçek için faktörlerin güvenilirliğini ölçmek için

Cronbach Alfa kullanılmıştır. Cevaplar 5'li likert (1=Kesinlikle katılmıyorum, 5=Kesinlikle katılıyorum) ölçeği ile alınmıştır. İşten Ayrılma Niyeti Ölçeği; Çalışmada yer alan İşten Ayrılma Niyeti algısını ölçmek amaçlı ölçeği Rosin ve Korabick (1995) tarafından geliştirilmiştir. Türkçe uyarlaması ise Tanrı̈̈ven (2005) tarafından yapılmıştır. Cevaplar 5'li likert (1=Kesinlikle katılmıyorum, 5=Kesinlikle katılıyorum) ölçeği ile alınmiştır. 


\section{Bulgular}

\section{Demografik Bulgular}

Araştırmaya katılan çalışanları tanımaya yönelik olarak oluşturulmuş demografik sorulara verilen yanıtların frekans analizi sonuçlarına göre; araştırmanın cinsiyet dağılımında kadın çalışanların ağırlıklı olduğu görülmektedir. Katılımcıların yaş dağılımları incelendiğinde \%69.70'nin 2631 yaş arasında, \%30.30'nun ise 18-24 yaş arasında oldukları görülmektedir. Katılımcıların öğrenim durumlarının sırasıyla; en fazla lisans (\%75.30), yüksekokul (\%13.10), yüksek lisans (\%11.10) ve lise (\%0.50) olduğu görülmektedir. Katılımcıların çoğu (\%60.10) bekardır. Katılımcıların hizmet süresi incelendiğinde sırasıyla; en fazla 1-3 yıl (\%73.20), 3-6 yıl (\%24.70) ve 7-10 yıl (\%2.00) olduğu görülmektedir. Katılımcıların departmanları incelendiğinde en fazla katılım, müşteri temsilciliği departmanından (\%59.60), en az katılım ise kalite yönetim departmanından (\%0.50) olmuştur. Katılımcıların statüleri incelendiğinde sırasıyla; en fazla katılım yetkililerden (\%81.30), uzmanlardan (\%12.60) ve yöneticilerden (\%6.10) sağlanmıştır.

\section{Nitel Araştırma Bulgulan}

Bu araştırmanın nitel bölümü olan yüz yüze mülakatlar 25 kişilik çalışma grubuyla gerçekleştirilmiştir. Z kuşağı çalışanlar ve yöneticileri ile derinlemesine görüşmeler yapılmıştır. Daha sonra bu görüşmeler içerik analizine tabi tutulmuştur. Verilerin Nvivo 11 nitel veri analizi ile kategorize edilmesi sağlanmıştır. Analizin gerçekleşmesi ile $\mathrm{Z}$ kuşağı bireylerinin en fazla tekrar ettikleri kelimelere ulaşılmış, böylelikle beklentilerine ilişkin kilit noktalar belirlenmiştir. Kelime sıklığı analizi sonucunda ön sırada olan bazı kavramlar (örneğin; bankacılık ve kuşak kelimeleri) bağlamdan ötürü kapsam dışı bırakılmıştır. Araştırmanın daha sonraki kısmı belirlenen kilit noktalar olan Z Kuşağı, Yenilikçi İnsan Kaynakları, Mutluluk, İşten Ayrılma Niyeti kavramları üzerinden literatür araştırması yapılması şeklinde devam etmiştir. 


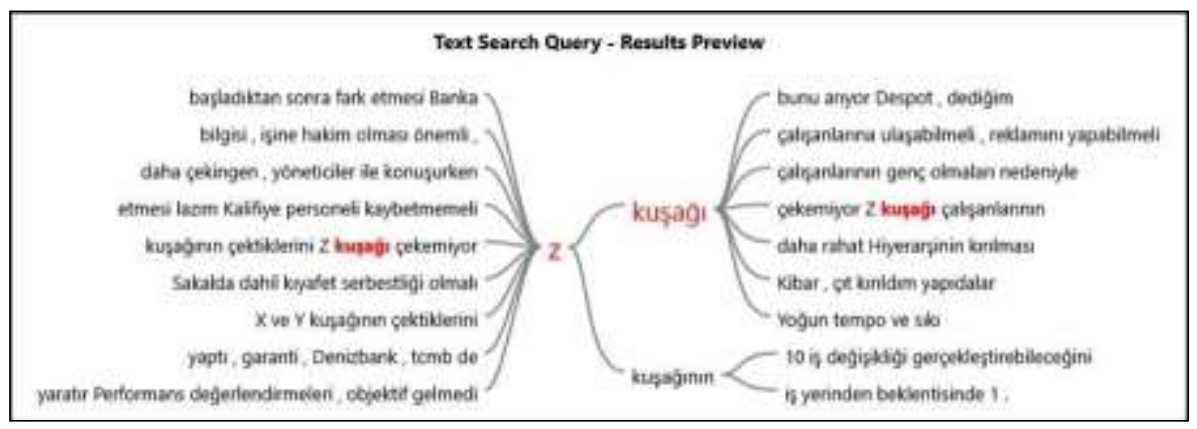

Şekil 1. Kelime Ă̆acı Analizi (Z Kuşă̆ı)

Şekil 1'de Z kuşağı çalışanlarının "Z kuşağı"nın iş hayatından beklentileri ve kendilerini ifade etmede kullandıkları serbestlik/esneklik, performans değerlendirmeleri, objektif olunması, hiyerarşinin olmaması, yoğun temponun etkileri gibi öne çıkan ifadeler yer almıştır.

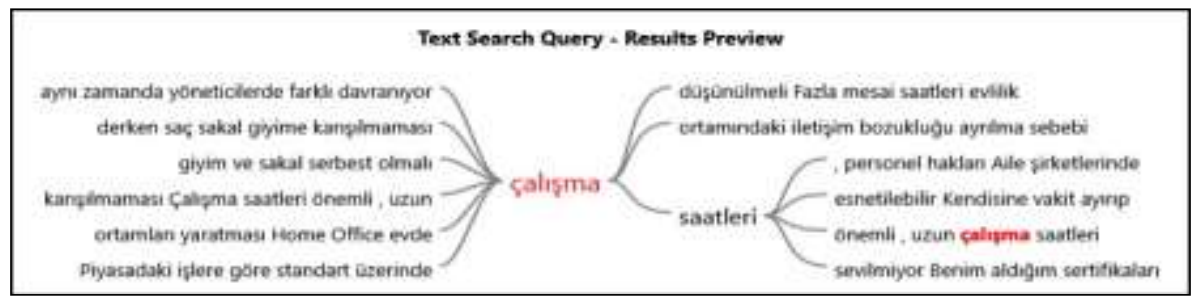

Şekil 2. Kelime Ă̆acı Analizi (Çalışma)

Şekil 2' de görülmekte olan "çalışma" kavramında; çalışanlar çalışma saatleri, fazla mesai saatleri, çalışma ortamı, esnek çalışma metotları, Home Office çalışma, standardın üzerinde performansta çalı̧̧ma gibi farklı türde çalışma özelliklerine değinmişlerdir.

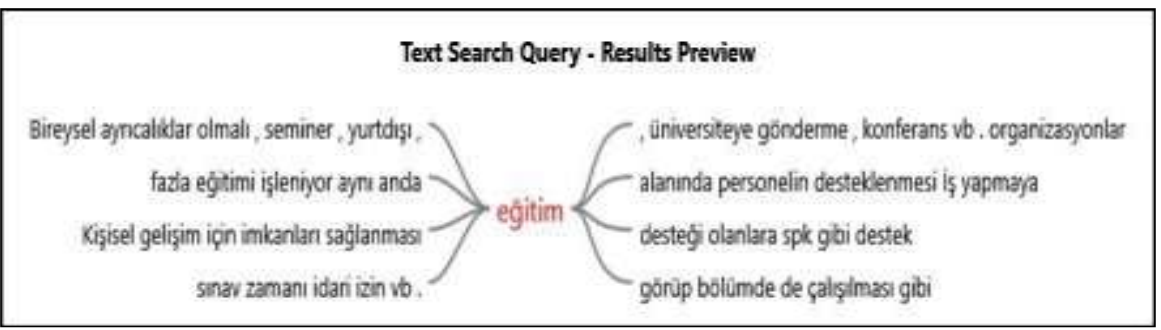

Şekil 3. Kelime Ă̆acı Analizi (Ĕ̆itim) 
Şekil 3'te görülmekte olan "eğitim" kavramında; eğitim seviyesi, seminer, eğitim türleri bulgular arasında ön plana çıkmıştır. Bulgular sonucunda Z kuşağ 1 çalışanlarının iş hayatında eğitim çeşitliliğinin önemli olduğu, her seviyede yer verilmesi gerekliliği ortaya çıkmıştır. İşe başlangıç öncesi, çalışma hayatı süresince ve hatta sonrasında da eğitimin sürekliliğini ayrıca kişisel gelişimleri alırken, aynı zamanda üstlendikleri görevleri içeren eğitimlerde talep etmektedir.

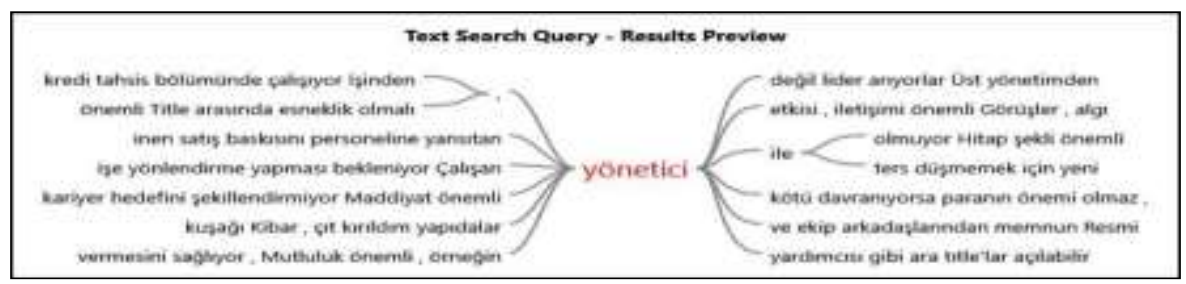

Şekil 4. Kelime Ağacı Analizi (Yönetici)

Şekil 4'te "yönetici" kavramında; Z kuşağı çalışanlarını yöneticilerin hitap şeklinin etkilediği, iletişimin önemli olduğu, üst yönetimden gelen iş baskısının ekibe yansıtılmaması gerektiği, yönetici davranışının maddiyattan önemli olduğu, gelecekteki kararlarında bu konunun etkili olduğu, beklentinin yönetici değil lider vasfının olması yönünde olduğunun altı çizilmektedir.

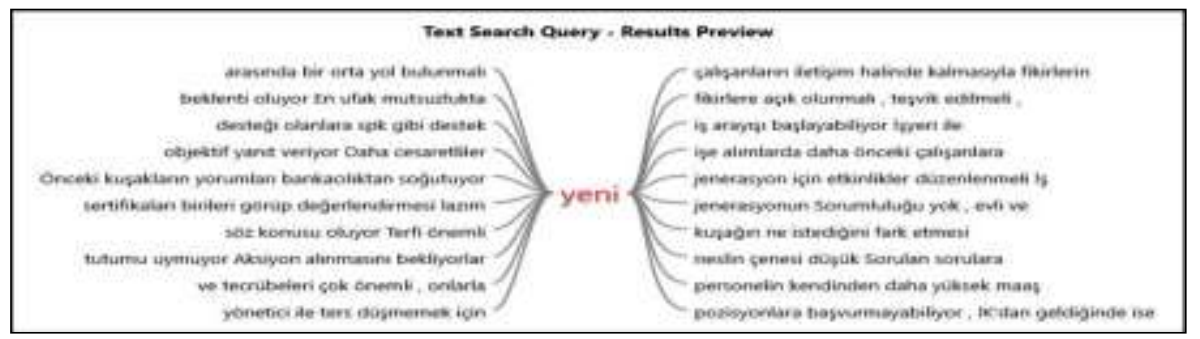

Şekil 5. Kelime Ă̆acı Analizi (Yeni)

Şekil 5'te yer alan "Yeni/Yenilikçilik" kavramında; Çalışanlar yeni fikirlere açık olunması, eğitim konusunda yeniliklere önem verilmesi, yeni pozisyonlarda değerlendirilmenin önemi konularında görüş bildirmişlerdir. 


\section{Nicel Araştırma Bulgular}

\section{Faktör ve Güvenilirlik Analizi Bulgulan}

Araştırmada kullanılan ölçekler öncelikle bütünleşik güvenilirlik analizine tabi tutulmuştur. Bütünsel güvenilirlik analizleri sonucu herhangi bir soru analiz dışı kalmadan faktör analizine geçilmiştir. Yenilikçi insan kaynakları uygulamaları bütünleşik güvenilirlik analizi sonucu ortaya çıkan Cronbach's alpha değeri 0,879 , faktör analizi sonucu ortaya çıan KMO değeri 0,842 ve Toplam açıllanan varyans değeri ise 71.236 olarak bulunmuştur. Yenilikçi insan kaynakları ölçeğinden 4 gizil (latent) değişken oluşturulmuştur. Faktör analizi sonucu S5 faktör yükünde $0,5^{\prime}$ ten küçük değer aldığı için analiz dışı kalmıştır. Yenilikçi insan kaynakları uygulamaları ölçeğinin alt boyutlarının güvenilirlik analizleri sonucu Cronbach's alpha değerleri sirasiyla $0,810,0,822,0,889$ ve $0,855^{\prime}$ dur.

Mutluluk bütünleşik güvenilirlik analizi sonucu Cronbach's alpha değeri 0,887, faktör analizi sonucu ortaya çıan KMO değeri 0,846 ve Toplam açıklanan varyans değeri 64.330 olarak bulunmuştur. Mutluluk ölçeğinden 4 gizil (latent) değişken oluşturulmuştur. Faktör analizi sonucu M6 ve M12 faktör yüklerinde yakın değerler aldıkları için analiz dışı kalmıştır. Mutluluk ölçeğinin alt boyutlarının güvenilirlik analizleri sonucu Cronbach's alpha değerleri sırasiyla 0,820, 0,812, 0,866 ve 0,745'dir.

Son olarak İşten Ayrılma Niyeti ölçeğinin bütünleşik güvenilirlik analizi sonucu Cronbach's alpha değeri 0,825, faktör analizi sonucu ortaya ç1kan KMO değeri 0,692 ve Toplam açıklanan varyans değeri 72.426 olarak bulunmuştur. İşten Ayrılma Niyeti ölçeğinin faktör yükleri tek boyutta toplanmıştır. Faktör yükleri açısından incelendiğinde Yenilikçi insan kaynakları uygulamaları: 0,528-0,887 ve Mutluluk: 0,530- 0,846 arası değerler almiştır.

\section{Regresyon Analizi Bulguları}

Araştırmanın bu hipotezi doğrultusunda mutluluğun aracılık rolü, Baron ve Kenny'nin (1986) önerdiği işlem adımları takip edilerek belirlenmiştir. Adımlar sırasıyla test edilmiş ve aşağıda sunulmuştur. 
Bağımsız (yordayıcı) değişken ile bağımlı (yordanan) değişken ilişkili olmadır. Bunun için YİKU'nün işten ayrılma niyetinin istatistiksel açıdan anlamlı olarak yordayıp yordamadığı test edilmiştir. Sonuç olarak YİKU'nün işten ayrılma niyetini, istatistiksel açıdan anlamlı olarak yorda$\operatorname{miştır}\left(R^{2}=.081, t_{(170)}=-3.866, p<.01 ; \beta=-.284\right)$. Ayrıca elde edilen bu sonuç H1 hipotezinin kabul edildiğinin göstergesidir.

H1: Yenilikçi İnsan Kaynakları Uygulamaları işten ayrılma niyetini anlamlı düzeyde etkiler.

Bağımsız (yordayıcı) değişken aracı değişken ile ilişkili olmalıdır. Bunun için YİKU'nün mutluluğu istatistiksel açıdan anlamlı olarak yordayıp yordamadığı test edilmiştir. Sonuç olarak YİKU mutluluğu, istatistiksel açıdan anlamlı olarak yordamıştır $\left(\mathrm{R}^{2}=.18, \mathrm{t}(171)=6.106, \mathrm{p}<.01 ; \beta=.424\right)$.

Ayrıca elde edilen bu sonuç $\mathrm{H} 2$ hipotezinin kabul edildiğinin göstergesidir.

H2: Yenilikçi İnsan Kaynakları uygulamaları mutluluğu istatistiksel olarak anlaml bir düzeyde etkiler.

Aracı değişken ile bağımlı (yordanan) değişken ilişkili olmalıdır. Bunun için mutluluğun işten ayrılma niyetinin istatistiksel açıdan anlamlı olarak yordayıp yordamadığı test edilmiştir. Sonuç olarak mutluluk, işten ayrılma niyetini istatistiksel açıdan anlamlı olarak yordamıştır $\left(\mathrm{R}^{2}=.125\right.$, $\left.\mathrm{t}_{(170)}=-4.931, \mathrm{p}<.01 ; \beta=-.354\right)$. Ayrıca elde edilen bu sonuç H3 hipotezinin kabul edildiğinin göstergesidir.

H3: Mutluluk işten ayrlma niyetini istatistiksel olarak anlamlı bir düzeyde etkiler.

Elde edilen bulgular özetlendiğinde, aracılık testi için gerekli olan tüm koşulların sağlandığı görülmüştür. SİKU ile işten ayrılma niyeti arasındaki ilişkide mutluluğun aracı etkisi hiyerarşik regresyon analizi belirlenmiştir. Analiz sonuçları Tablo 1'da sunulmuştur.

Tablo 1 incelendiğinde Model 1'de YİKU'ye ilişkin beta ( $\beta$ ) katsayısının -0.284 olduğu, modele alınan mutluluk değişkeniyle Model 2'de YİKU'ye ilişkin $\beta$ katsayısının - 0.164 'e yükseldiği görülmektedir. Elde edilen bu sonuç, $\beta$ katsayısının artmasının istatistiksel açıdan anlamlı olmasından, mutluluğun aracllık etkisine sahip olduğunu göstermektedir. Bu etkinin istatistiksel açıdan anlamlılığı Sobel testi ile araştırılmıştır. Sobel testi sonucuna göre mutluluğun aracı etkisi istatistiksel açıdan anlamlı çıkmıştır 
$(\mathrm{z}=-5.72 ; \mathrm{p}<.01)$. Elde edilen bu sonuç $\mathrm{H} 4$ hipotezinin kabul edildiğinin göstergesidir.

Tablo 1. YíKU İle İşten Ayrılma Niyeti Arasındaki İlişkide Mutluluğun Aracı Rolüne İlişkin Hiyerarşik Regresyon Analizi Sonuçları

\begin{tabular}{lccccc}
\hline & Model & $\Delta \mathbf{R}^{2}$ & $\mathbf{B}$ & SHв & $\boldsymbol{\beta}$ \\
\hline Model 1 & Sabit & & 11.694 & 1.278 & \\
& YíKU & $.081^{* *}$ & -0.090 & 0.023 & $-.284^{* *}$ \\
\hline Model 2 & Sabit & & 16.395 & 1.791 & \\
& YíKU & $.066^{* *}$ & -0.52 & .025 & $-.164^{* *}$ \\
& Mutluluk & & -0.098 & .027 & $-.284^{* *}$ \\
\hline
\end{tabular}

${ }^{* *} p<.01$;

Model 1: Bă̆ımsız değişken: YIKKU, Bağımlı değgişken: İşten ayrılma niyeti

Model 2: Bağımsız değişkenler: YİKU, Mutluluk, Bă̆ımlı değgişken: İşten ayrılma niyeti

H4: Yenilikçi İnsan Kaynakları uygulamaları ile işten ayrılma niyeti arasında mutluluğun aracılık etkisi istatistiksel olarak anlamlıdır.

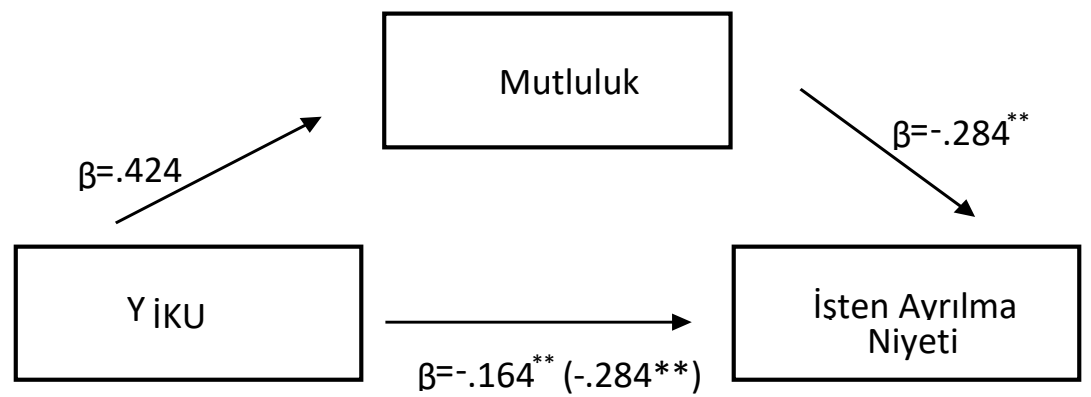

Şekil 1. YİKU İle İşten Ayrılma Niyeti Arasındaki İlişkide Mutluluğun Aracı Rolüne İlişkin Beta Katsayılar

Ayrıca Model 1'de işten ayrılma niyetindeki varyansın yaklaşık \%8'i YİKU ile açılanırken, modele mutluluğun dahil edilmesiyle oluşan Model 2'de işten ayrılma niyetindeki varyansın yaklaşık \%15'i YİKU ve mutlulukla birlikte açıklanmıştır.

Regresyon eşitliğinden de anlaşıldığ işten ayrılma niyeti azalmaktadır. 


\section{Tartışma ve Sonuç}

Tarihsel süreç boyunca gerçekleşen olaylar bireylerin karakteristik özellikleri, istek ve beklentileri açısından farklılaşmalarına sebep olmuştur. Kuşak kavramı uzun yıllardır üzerinde çalışılan, adlandırılması ve tarihsel sınıflandırılması konusunda kesin bir fikir birliğine varılamayan konudur.

Araştırmamızın konusu olan Z kuşağı çalışanları ise karakteristik olarak, gelişen teknolojiye hakim, eğitim ve gelişime önem veren, kendi kariyer yollarının farkında olan, maddi imkanlardan ziyade manevi doyum ve iş tatmini arayan, hiyerarşik yapıya uyum sağlamak istemeyen ve esnek çalışma koşulları arayan, işyeri bağımlılıklarının düşük olmasını içeren genel özellikler sergilemektedir.

Rekabet ortamında uzun vadede kar etmek isteyen işletmelerin, $\mathrm{Z} \mathrm{Ku}$ şağı'nın çalışma hayatına dahil edilmesi ve mevcut iş yerinde tutulabilmesi için, öncelikle İnsan Kaynakları Yönetimleri olmak üzere tüm kademelerdeki yönetsel pozisyonlarına önemli görevler düşmektedir.

Demografik özellikler dikkate alındığında; sektördeki Z kuşağının Kadın çalışan oranı üst seviyelerdedir. Öğrenim durumundaki en yüksek oransa Lisans seviyesinde ve 1-3 yıl hizmet süresi aralığında olan kuşak çalışanlarının henüz yetkili statüde görev aldığı görülmüştür. Sektörde eğitimli, genç ve dinamik aktörler olarak yer alan $\mathrm{Z}$ kuşağı çalışanlarının ilk yöneticileri ve diğer kuşak çalışanları tarafından anlaşılmaları, İnsan Kaynakları Uygulamalarının etkin kullanımı ile mutluluk düzeylerinin arttırılması, işten ayrılma niyeti düşürülerek mevcut iş yerlerini tercih etmeleri sağlanabilecektir.

Araştırmada kullanılan ölçekler ve bu ölçeklere ait alt faktörlerde; Mutluluk ölçeği kapsamında, Bireysel Gelişim Mutluluğu, Bireysel Yaşam Mutluluğu, İş Yaşamı Mutluluğu ve Sosyal Yaşam Mutluluğu için cinsiyet özellikleri açısından anlamlı bir farklılık bulunmamaktadır. Ancak 1995 sonrası doğumlu 18-24 yaş aralığındaki çalışanlar için Bireysel Gelişim Mutluluğu ve Sosyal Yaşam Mutluluğunun, 1990-1995 yıl aralığında doğanlara göre anlamlı düzeyde farklı olduğu görülmüştür. Bu durum 1995'den sonra doğan bireylerin özellikle bireysel gelişim ve sosyal yaşamda mutluluğa daha fazla önem verdikleri anlaşılmaktadır. Yönetsel 
kararlarda bu iki faktör öncelikli dikkate alınmalıdır. Söz konusu çalışanlar için eğitim uygulamalarının yakinen takibi sağlanmalıdır. Özellikle yeteneklerini geliştirebilecekleri özgün çalışma ortamları sağlanması ile fark yaratabilecekleri görev tanımları belirlenmesi iş tatminlerini arttıracaktır.

Stratejik insan kaynakları alt faktörlerinde; Performans Yönetimi açısından kadın katılımcların oranının daha yüksek olduğu, etkin kariyer yolu ve performans değerlendirme yönetimlerinin esas alınması ile $\mathrm{Z} \mathrm{ku-}$ şağı kadın çalışanlarına hitap edilebileceği anlaşılmaktadır. İşe Alım ve Seçim, Eğitim, Yenilikçilik konularında ise cinsiyet ve yaş açısından anlamlı bir farklılığın bulunmadığı görülmüştür. Ancak kariyer hedeflerinin farkında olan Z kuşağının insan kaynakları fonksiyonlarından beklentisi yüksektir. Bu konuya yüksek duyarlılıkla yaklaşılmalıdır. Özellikle ilk yöneticilerinin kendilerini anlamaya çalışması, performans takibi yaparak düzenli aralıklarla geri bildirim vermesi beklentileri mevcuttur. Çalışanlarının özelliklerinin farkında olan, bir değer olarak gören işletmeler böylelikle işletmelerine de değer katacak ve rakiplerine karşı önemli bir fark yaratacaktır.

İşten ayrılma niyeti açısından cinsiyet ve yaş kriteri anlamlı bir farklılik oluşturmamaktadır.

Çalışma bir bütün olarak öncelikle Z kuşağının anlaşılması yönünde bir rehber niteliğindedir. Kuşağın kendisini kendi cümleleri ile tarif ediyor olması, sektörden ve genel olarak iş hayatından beklentilerinin netlikle ifade edilmiş olması, kariyer yollarının belirlenmesi ve bu kuşağın işletmede tutulması açısından önemli bilgiler içermektedir.

Araştırmada yalnızca 1990 sonrası aktif banka çalışanlarına yer verilmiş olması araştırmanın kısıtı olarak karşımıza çıkmaktadır.

Araştırma kapsamında ortaya çıan hipotezlerin tamamı doğrulanmıştir. 


\section{EXTENDED ABSTRACT}

\section{The Effect of Innovative Human Resources Practices on Happiness and Intention to Leave of $Z$ Generation: A Mixed Method Research in the Banking Industry}

Nihal Güler - Pınar Acar

*

Bahçeşehir University - Beykoz University

The resource based view which makes up the conceptual infrastructure of our research suggests that the business resources should be precious, rare, without substitution and inimitable in order to achieve sustainable competitive advantage. In this regard, one may suggest that competent employees with high potential are rare and precious resources for businesses. We suggest that it is possible to increase the happiness of employees and reduce their intention to leave through successful and innovative human resources practices. All businesses operating in their sectors need human resources notwithstanding their field of business. And human resources management is the total of the activities and tasks performed without discrimination within personal, organizational and environmental dimension in order to achieve the targeted objectives effectively and efficiently in the field of human resources of the organization undertaking the aforementioned task (Türedi, 2018, p.4-5).

Ensuring the human resource to continue to be employed is as important as recruitment of the human resource. Resignation of trained personnel leads to negative influence on productivity and profitability in all sectors. The intention to leave is the thought of the employee related to his/her will to resign in the near future. It is necessary to define the factors that affect the intention to leave because the investments that corporations make for their employees are indeed investments made for the future. Furthermore, the cost of the employees has a significant share in the total 
costs of any corporation (Şahin, 2011, p.277). The intention to leave is related to existence of any thoughts or plans of the employees for resigning from their current jobs or from their business places in any specific process. The intention to leave may be explained with the employee having a thought of resigning from his/her current job or from his/her business place in any specific process (Fong and Mahfar, 2013, cited by Barlett, 1999). Being happy in the working environment attracts the attention as a significant issue for the person who passes a significant portion of his/her life working.

Schuler who expresses the strategic dimension of the Human Resources Management (HRM) as "integration" and "adaptation" taking it in a broader context explains this context as "the strategic structure of the human resources management aims at integration of human resources practices in organizations with the strategy and strategic requirements of the company".

Besides, when the researches conducted on the generations, there is no universally agreed and recognized consensus on naming the generations and classification of the same in specific periods. It has been concluded that concentration in specific periods and generation definitions was in question in the literature. Classification of Oblinger and Oblinger (2005) who takes 1991 and later as basis for classification of $\mathrm{Z}$ generation has been taken into consideration in this research.

On the other hand, the thing that humans determine and give meaning as the purpose of their life within the time from the moment of birth till the moment of death has been happiness. For this reason, the humans searched for the means for achieving happiness. Individuals looked for happiness that has been desired from the origin of humanity to date within the society and many researches have been conducted for many years on what it meant and how it could be achieved (Acaboğa 2007, p.3, aktaran Akdeniz, 2016, p.46).

Furthermore, happiness at work also important for motivation. If the employee is not happy at work than they may have an intention to leave the organization. Resignation of the employees may impact the organization negatively. Such negative aspects may be listed as corruption of the business order, performance losses and decrease in the current motivation of the employee. The point to be emphasized here is the qualification of 
the employee who resigns. If any employee with high qualification resigns from the organization, negative effects for the organization shall be mentioned while it is possible to mention positive effects for the organization when any employee with lower qualification resigns.

Concordantly, the basic purpose of this research is to reveal the impact of innovative human resources practices on happiness and intention to leave of $Z$ generation employees. Our research was conducted using mixed method containing both qualitative and quantitative research design. It was revealed as a consequence of our findings that happiness of $Z$ generation had mediator effect in the relation between innovative human resources practices and the intention to leave.

It has been revealed that the happiness level of $Z$ generation employees shall increase through innovative human resources models of organizations sensitive to their tendencies and requirements and this would positively impact the behaviors of resignation.

On this basis, the businesses are required to produce solutions which integrate digitalization processes to their structures, which are education focused, which contribute to development and which could respond the expectations of $Z$ generation. The businesses may follow intention to leave of $Z$ generation through activities such as satisfaction surveys, face-to-face interviews etc. to be performed in definite periods, may take convenient measures necessary for innovative human resources practices and play active role in keeping the qualified employee in the organization.

Additionally, there are very different opinions on the issues of classification and naming the generations and there is no consensus. The research contains separate assessment of the employees born in and after 1990 and 1995 in terms of classification of $Z$ generation and it makes up an exemplary model for tendencies and similarities of the employees in both classes. The research aims at contributing to the literature for this aspect as well.

\section{Kaynakça / References}

Ahat, K., (2018). Bilincin moda yönelimine etkisi:Moda bilinci, öz-bilinç ve öznel mutluluk üzerine alan araştırması. Yayımlanmış Doktora Tezi, Selçuk Üniversitesi, Sosyal Bilimler Enstitüsü, Konya. 
Akdeniz, M. Z., (2016). Paternalistik liderlik ve örgütsel adaletin çalı̧̧anların mutluluklarına olan etkisi: Sağlık sektöründe bir uygulama. Yayımlanmış Yüksek Lisans Tezi. Bahçeşehir Üniversitesi, Sosyal Bilimler Enstitüsü, İstanbul.

Demir, R., (2017). Öğretmen adaylarının mutluluk, iyimserlik, yaşam anlamı ve yaşam doyumlarımın incelenmesi. Yüksek Lisans Tezi, Gaziantep Üniversitesi Eğitim Bilimleri Enstitüsü, Gaziantep.

Erkuş, A., Tabak, A. ve Yaman, T. (2010). Paternalist (Babacan) liderlik çalışanların örgütsel özdeşleşmelerini ve işten ayrılma niyetlerini etkiler mi: Bir özel hastane uygulaması. 9. Ulusal İşletmecilik Kongresi Bildiri Kitabı (s.594-598), 9. Ulusal İşletmecilik Kongresi, 6-8 Mayıs 2010, Zonguldak.

Gözde, A., (2018). Örgütsel adalet algısı, örgütsel vatandaşlık davranışı, işten ayrılma niyeti ve örgütsel insandışılaştırılma algısı arasındaki ilişkiler. Yayımlanmış Yüksek Lisans Tezi, Abant İzzet Baysal Üniversitesi, Sosyal Bilimler Enstitüsü, Bolu.

Gül, S., (2017). Mutluluk ekonomisi ve göz üzerine bir inceleme. Doktora Tezi, Marmara Ünversitesi, Sosyal Bilimler Enstitüsü, İstanbul.

Gürbüz, S. ve Bekmezci, M., (2012). İnsan kaynakları yönetimi uygulamalarının bilgi işçilerinin işten ayrılma niyetine etkisinde duygusal bağlılığın aracllık ve düzenleyicilik rolü. İstanbul Üniversitesi İşletme Fakültesi Dergisi, 41 (2), 189-213.

Fisher, C. D. (2009). Happiness at work. International Journal of Management Reviews, 12, 384-412. doi: 10.1111/j.1468-2370.00270.x

Hampton, D. C. ve Keys, Y. (2016). Generation Z students: Will they change our nursing classrooms? Journal of Nursing Education and Practice, 7 (4), 111-115.

İzmirlioğlu, K. (2008). Konumlandırmada kuşak analizi yardımıyla tüketici algılarının tespiti Türk otomotiv sektöründe bir uygulama. Yayımlanmış Yüksek Lisans Tezi, Muğla Üniversitesi Sosyal Bilimler Enstitüsü, Muğla.

Jafarova, F. (2018). X-Y kuşă̆ı çalışanlarmmn iş tatmini, örgütsel bağlılık ve işten ayrılma niyetinin karşılaştırılması: Beyaz yakalı çalışanlar üzerine bir uygulama. Yayımlanmış Yüksek Lisans Tezi, Aydın Üniversitesi, Sosyal Bilimler Enstitüsü, İstanbul. 
Mameghani, S.S. (2017). Türkiye ve İran'daki üniversite öğrencilerinin affetme, tolerans ve mutluluk düzeylerinin karşılaştırılması. Doktora Tezi, On dokuz Mayıs Üniversitesi, Eğitim Bilimleri Enstitüsü, Samsun.

Okumuş, B. E. (2016). Kuşak farkı özelliklerine göre şekillenen ofis iç mekan tasarımı kriterlerinin irdelenmesi $Y$ ve $Z$ kuşağı üzerine araştırma ve model önerisi. Doktora Tezi, Mimar Sinan Güzel Sanatlar Üniversitesi Fen Bilimleri Enstitüsü, İstanbul.

Rüzgar, N. (2018). Çalşanların, insan kaynakları yönetimi modelleri ile yöneticilerinin mizah tarzlarına ilişkin algzlarmın iş tatminleri üzerindeki etkisinin incelenmesi. Yayımlanmış Doktora Tezi, İstanbul Ticaret Üniversitesi, Sosyal Bilimler Enstitüsü, İstanbul.

Singh, A. (2014). Challenges and issues of generation Z, IOSR Journal of Business and Management, 16(7), 59.

Toruntay, H. (2011). Takım rolleri çalışması: X ve Y kuşağı üzerinde karşılaştırmalı bir araştırma. Yayımlanmamış Yüksek Lisans Tezi, İstanbul Üniversitesi Sosyal Bilimler Enstitüsü, İstanbul.

Tulgan, B. (2013). Meet generation Z: The second generation within the giant "millenial" cohort, Rainmaker Thinking, 1-12.

Türedi, Ö.M. (2018). Türkiye'nin önde gelen girişimcilerinin insan kaynakları yönetimi uygulamalarına bakış açısı ve nitel bir araştırma. Yayımlanmış Yüksek Lisans Tezi, İstanbul Üniversitesi, Sosyal Bilimler Enstitüsü, İstanbul.

Oblinger, D. ve Oblinger J. (2005). Educating the net generation, North Carolina State University, Washington, D.C.: EDUCAUSE, 2-9.

Yapıcı-Akar, N., Dirlik, O., Kıymalığlu, A., Yurtseven, Ö. ve Boz, H. (2011). Uluslararası insan kaynakları yönetimi alanındaki güncel eğilimlerin stratejik yaklaşımlar ve bölgesel modeller açısından değerlendirilmesi: 1998-2008 kesitinde bir inceleme. Business and Economics Research Journal, 2 (4), 98-99. 


\section{Kaynakça Bilgisi / Citation Information}

Güler, N. ve Acar, P. (2019). Yenilikçi insan kaynakları uygulamalarının z kuşağının mutluluğuna ve işten ayrılma niyetine etkisi: bankacılık sektöründe karma yöntem araştırması. OPUS-Uluslararası Toplum Araştırmalar Dergisi, 12(18. UİK Özel Sayıs1), 563-585. DOI: 10.26466/opus.585393. 